Metodički obzori 6(2011)2

Original scientific article

UDK: 379.81-052.5

Received: 14. 8. 2010.

\title{
STIMULATING ACTIVE LEARNING IN EXTRACURRICULAR ACTIVITIES THROUGH CONTEMPORARY WORK STRATEGIES
}

\author{
Petra Pejić Papak, MSc \\ Faculty of Education, University of Rijeka (Croatia) \\ e-mail: petra@ufri.hr \\ Sabina Vidulin-Orbanić, PhD \\ Department of Music, Section of Music Pedagogy, \\ University Jurja Dobrile of Pula (Croatia) \\ e-mail: svidulin@unipu.hr
}

\begin{abstract}
A b stract
The contemporary school distinguishes itself with its proficiency in successfully preparing and leading the educational process, as well as in selecting the appropriate procedures, methods, forms of interaction, media and technology for doing so. Opening the school to the needs of youth and children also after regular classroom activities is important so that, in addition, the school may spread its educational role to the free time of its pupils. Thus, extracurricular activities are, and will remain, an efficient site upon which contemporary educational goals can be realised, and a site on which contemporary teaching strategies that aim towards the pupils' development and progress are successfully implemented. By participating in variously themed extracurricular activities, the pupil is given the opportunity to utilise various work strategies through autodidacticism, active participation and independent (self)development. The use of modern strategies organises the pupils' activities in a less restrained fashion so that they may, by connecting theory and practice, expand and deepen the knowledge they have acquired, develop their skills, and also become active participants in cultural events in their environment. Using a research approach based on a sample of 257 leaders of extracurricular activities in the junior grades of primary school, the aim of this work was to ascertain the leaders' views on the significance of organisation and implementation as determinants in extracurricular activities, on the stimulation of active learning through contemporary strategies pertaining to the areas of interest in question, and on the determination of stimulating factors that could contribute to the promotion of active learning in extracurricular activities.
\end{abstract}

Key words: primary school, extracurricular activities, contemporary strategies, active learning, leaders of extracurricular activities 


\section{Introductory Thoughts}

The issue of the successfulness of the educational process is not an issue that pertains solely to the 21 st century. Foreshadows of a democratic and creative school oriented towards the pupil can be identified in W. von Humboldt and G. Kerschensteiner's aspirations towards a universal education, the theories of Klafk and Schulz, the alternative attempts of the Dalton Plan, the Winnetka Plan and the Gary Plan, and schools and systems such as Montessori and Waldorf. The stated reforms and orientations have contributed towards scholarly pluralism and offered new learning forms, methods and contents, thus contributing to the specific structure of education (Robinson, 2003), and particularly its practical characteristics.

An optimal organisation of lessons and a selection of successful methods influence the activity of pupils, while the contemporariness of teaching materials and methods leads to easier, faster, clearer and more rational, economic and productive learning and teaching. It is precisely the skill of successfully preparing and leading, and of utilising appropriate procedures, methods, forms of interaction, media and technology that distinguishes a modern and open institutional education. Such an education leads towards a quality school and a society of knowledge, empowers both the individual and the group and leads to the formation of professional and innovative, humane and socially oriented community members. Through various activities and materials, the use of modern media and teaching strategies that correspond with global cultural and civilisation development, the creativity of pupils is also stimulated. For the reasons stated, we can conclude that a quality school merges a contemporary approach to lessons with learning topics adapted to contemporary knowledge and revelations, thus allowing participants in education a holistic development and continuous personal improvement (Bartlett, 2003).

The contemporary school has continued with the tendencies and the intentions of reformative orientations in pedagogy that stimulated the opening of schools to the needs of youth and the expansion of its educational values to the extracurricular, leisure time of young people, as well. Thus pupils gather according to various activities: sport, music, science, research etc. This means that the school has offered its pupils the option to spend their free time in the quality and professional environment of extracurricular activities, with the aim of individual educational development.

The successfulness of a contemporary school is reflected precisely in the manner in which it establishes connections between its pupils, its teachers and its educational content (Baker, 2002); this influences the pupils' progress, enriches their knowledge and develops their skills - therefore, preparing them for life.

We maintain that the right means for the targeted development of pupils are none other than extracurricular activities, as they optimally organise the free time that students have after regular classes. Let us also mention that pupils independently select how to spend their leisure time and which activities to join, actively participating in the work and impelling themselves to innovativeness and creativity. In this manner, they develop their personalities, acquire knowledge and develop their skills while experiencing, perceiving and evaluating mankind's cultural, scientific, technical and sports achievements. They become familiar with the quality and aesthetically valuable 
attainments of our civilisation, which influences their general knowledge. In addition, they acquire the culture of using their leisure time well.

Extracurricular activities are efficient site upon which contemporary educational goals can be realised, and a site upon which teaching strategies that facilitate learning are successfully implemented. Through variously themed activities, pupils have the opportunity to use strategies of spotting differences and similarities, of summarisation and notation, of increasing effort and giving recognition, of practicing, reviewing, cooperative learning, giving feedback, creating and testing hypotheses and of forming questions (Marzano, Pickering, Pollock, 2006). Therefore, it is important to raise consciousness on the role and value of extracurricular activities and the possibilities they offer, and to stimulate their organisation and implementation. The value of the successful implementation of the aforementioned is also reflected in the fact that extracurricular activities enrich the life of a school, often giving it a distinctiveness that makes it recognisable within its environment.

\section{The Educational Principles of Work in Extracurricular Activities}

Contemporary educational and pedagogical documents ${ }^{1}$ officially use the term of extracurricular activities. Previšić $(1987,24)$ stresses that extracurricular activities are "an integral and equal part of the structure of educational work in our schools", while Puževski $(1988,24)$ uses the term extracurricular activities to indicate "all the forms of activities, work and life that students of a school partake in and which are organised outside regular lessons (student groups, societies, organisations and communities)". Puževski $(1988,26)$ also highlights the following: "The first idea, one that today bears the significance of a viewpoint, from which one should commence both in discussion and in the construction of immediate pedagogical practice, is the idea that extracurricular activities are not lessons, but a special form of a school's pedagogical work". Therefore, these activities represent planned educational endeavours that are executed within the framework of the school, outside regular lessons, and which provide an area of interest and, in addition, an all-round affirmation of a pupil's personality. To the teacher, they provide an expanded educational influence on the school population.

We can view extracurricular activities from two perspectives: a narrower and a broader one. From a narrower point of view, extracurricular activities are part of the "school package" occurring after regular lessons, while a broader perspective relates to the possibility of opening the school towards the wider community. A narrower understanding of extracurricular activities, one oriented towards the school, can be found in Pedagoška Enciklopedija I (Pedagogical Encyclopaedia I) $(1989,299)$, where it is stated that "extracurricular work encompasses the various activities of pupils within the school and organised by the school, but outside the curriculum and the programme of

\footnotetext{
${ }^{1}$ Nastavni Plan i Program (Education Plan and Programme), Zakon o Odgoju i Obrazovanju u Osnovnoj Školi (Primary School Education Act), Državni Pedagoški Standard Osnovnoškolskog Sustava Odgoja i Obrazovanja (State Pedagogical Standards for Primary School Education), Nacionalni Okvirni Kurikulum za Predškolski Odgoj i Opće Obvezno Obrazovanje u Osnovnoj i Srednjoj Školi (National Curriculum Framework for Preschool Education and General Compulsory Primary and Secondary Education)
} 
regular lessons". It is evident that the educational work of the school is continued through them, only during the pupils' free time and, which is exceptionally important, with the implementation of special work strategies. On the other hand, thanks to the enthusiasm of education workers - the bearers of these activities - and an interested group of pupils, the school opens its doors to everything that surrounds it: other schools, pupils, teachers, professionals and professional associations (Katalog Natjecanja i Smotri/Catalogue of Competitions and Festivals, 2006).

Considering the equal importance of both education and upbringing in the shaping of a contemporary individual, let us also mention that educational work in extracurricular activities, in addition, offers the opportunity of continuously applying child rearing principles in work. Although activity leaders have to invest maximum effort, knowledge, patience and will for a change to occur in the pupil, a lot also depends on the pupil himself. The success of educational work is the fruit of a mutual, cooperative relationship. In this sense, the efficacy of education and rearing is manifested in the use of the principles of uniqueness in work, in a respect for differences between pupils, the recognition and satisfaction of basic needs and the use of varied work methods and tools, while activating pupils through work and a cooperation that aims towards the self-rearing of the child. All of these principles are equally important and useful. There is no hierarchical relationship between them. Differences may occur only in relation to the situation at hand. It is wrong to think that a principle can perform the job of educating all by itself, without concrete activities planned by the teachers and pupils.

Let us stress that a teacher's enthusiasm is not sufficient for good educational work and management of extracurricular activities, as teachers also need to be qualified for this work - professional knowledge and methodical preparation are necessary. The pupils' creative productivity largely depends on the teacher's professional competences, actions, work methods and his relationship with his pupils. The teacher's knowledge, abilities and experience are brought forward in his work on informing, orienting, planning, organising and conducting extracurricular activities with pupils. The pedagogical role of a teacher involved in extracurricular activities is manifested in assisting, inciting, coordinating, counselling, teaching and directing pupils towards a correct, cultured and rational usage of leisure time.

In everyday life and, in particular, in the area of education, the importance of giving significance to lifelong learning and development is incessantly stressed. Professional development is based on the constructivist learning theory model. It is a continuous, long-term process tuned to the needs of everyday lessons and learning. This process presupposes continuous support from the system and the self-evaluation of teachers/practitioners who explore their own practice and deliberate upon it.

A professional teacher, an interested group of students, a classroom equipped with adequate means and aids, investing effort into an activity, and also the support and understanding of the school and the environment are all prerequisites for the quality implementation of extracurricular activities and the enrichment of pupils' experiences. 


\section{Work Strategies in Extracurricular Activities}

As pertaining to areas of interest in the organisation extracurricular activities for primary school children, the National Primary School Plan and Programme (2006) divides extracurricular activities to: the linguistic/artistic area, the natural sciences/mathematics area, the sports/health/recreation area, the area of fostering national and cultural heritage, the area of preserving the environment, nature and a healthy lifestyle, social/humanistic projects and workshops, the area of pupil cooperation and the area of technical work. Extracurricular activities are carried out in groups within the aforementioned areas of interest.

The programme of every activity ought to respect not only the needs of the pupils, but also the needs of the school and the community. Programmes are "the expression of the creative efforts of the school, the social and political community and of pupils' wishes" (Previšić, 1987, 40). The affinities of pupils and teachers, planned activities, the manner in which activities are conducted, the needs and the culture of the social environment - these are but few of the factors with which the teacher ought to be acquainted with when organising extracurricular activities. Planning extracurricular work demands an excellent knowledge of the social, psychological, pedagogical, didactical and professional dimensions of teaching.

In planning his work in extracurricular activities, the teacher is led by the goal and the purpose of every single activity. In this manner, he allows pupils to acquire new knowledge and skills and promotes a general culture of communication, raising awareness on the need for better interaction and socialisation.

There are several basic prerequisites necessary for the quality management of extracurricular programmes. These relate to a free selection of activities, the professionalism of their leaders and the use of contemporary forms, methods, programmes and organisation. Therefore, the students ought to have the option of freely selecting from a diverse array of quality extracurricular activities at the beginning of the school year. Furthermore, leaders of extracurricular activities should possess professional knowledge and an affinity towards the area they are leading, while also systematically pursuing the latter. The material, technical and other conditions necessary for the satisfactory conduction of extracurricular programmes also ought to be ensured; it is necessary to use diverse forms, methods and procedures. The creative capabilities of each student should be stimulated and developed with a quality programme, one with many diverse approaches to the implementation and execution of the same.

In discussing the issue of extracurricular activities, what does the term of contemporary strategy specifically presuppose? Here we are not implying only the preparation and organisation of the same activities, but also the contemporariness (quality) of the programme, content, forms and work methods that are being executed. The manners and methods of execution ought to take the form of a workshop, project, group research or independent research, as such a method of work contributes to the contemporariness of education. Work should be free, open, unhampered, dynamic and varied. The pupils' interests and their wishes, affinities and talents ought to represent an important starting point. 
Such a process of "active learning" presupposes various activities of pupils who learn together with those who teach them. It can be viewed from two angles: that of the pupil and that of the teacher, while its key feature is its shifting of focus to the pupil as an active, participatory constructor of his own knowledge. The achievement of higher levels of understanding and motivation through such active learning satisfies the demands of constructivism, whose teachings are based on: the importance of previous knowledge, immediate experiences in reality, the holistic nature of experience, the reflexivity of learning and teaching, pupils' creativity, inner motivation, the role of the teacher, the method of holistic teaching. Considering that the pupil is involved immediately and focused on carefully selected activities, he is in the position to deliberate on what he is doing. In this manner, he constructs a system of logically connected knowledge that he will be able to utilise in various situations in life. By using creative teaching as a starting point, utilising strategies and methods that stimulate the development of active learning and critical thinking and by introducing cooperative and experiential learning models specific interests are developed, while the pupils' understanding and application of acquired knowledge is also improved. In order to achieve this, it is essential to include elements of "positive co-dependence, individual and group responsibility, the stimulation face to face interaction, social skills as well as group processing" (Cota Bekavac, 2001, 32) in cooperative activities.

Let us also mention the following. By using contemporary work strategies in extracurricular activities, the work of gifted pupils can be discovered, stimulated and monitored, and it is also easier and faster to discover and guide such pupils in these circumstances; contemporary work strategies are an opportunity for a better social integration, the foundation for spending leisure time in a quality manner, they enable a permanent education of its participants and act as prevention against negative influences from the environment.

Extracurricular activities should realise goals and tasks that cannot be realised within regular lessons. One should aim towards offering activities that are in tune with current events, and thus contribute to the broadening of the pupils' horizons. In this manner, a possibility is opened for extracurricular activities to become a valuable and important area for nurturing and fostering a child's positive qualities, and for stimulating and developing individual abilities and the corresponding skills.

With the introduction of extracurricular activities into schools, new opportunities for the additional involvement of young people are opened, as is the opportunity for their versatile development and education. Contemporary strategies organise pupils' activities in a freer fashion, according to their interests and affinities, in order for them to expand and deepen the knowledge they have acquired by connecting theory and practice, and to deepen their need for cultural events in their leisure time. Cindrić $(1992,49)$ stresses that the starting point for organising extracurricular activities lies precisely in "the need of young people for association, the autonomy of the school, the individual/group/class as possible forms of action to satisfy pupils' interests, improving the quality of life, socialisation and preparing pupils for their future lives, a mentor approach to the (self)organisation of pupils". The pupils' enthusiasm for further work, activity and effort stems from the fact that the activity was voluntarily chosen, is flexible in its tasks, has an open approach and is held in a comfortable environment. In respect of the 
aforementioned, pupils are motivated for work and for studying a certain topic or area which, therefore, immediately affects their development.

It is important to stress that neither the Educational Plan and Programme nor the National Curriculum Framework prescribe, elaborate or officially determine the content of extracurricular activities, thus teachers (and pupils) have the option of suggesting topics and activities according to their area of interest, which we consider a great organisational advantage. The Educational Plan and Programme $(2006,13)$ stresses the following: "Extracurricular activities in primary school imply teacher's freedom in creating educational activities and his sense of creativity, while at the same time representing a successful stimulus for involving pupils in work outside regular lessons". In accordance with this, and depending on the area of interest, work conditions, the needs of the school and the wider community, new activities, contemporary forms, methods and strategies of work are brought into the programmes of extracurricular activities as new means of achieving planned goals and tasks.

In order to make the aforementioned feasible, not only is the teacher necessary as an initiator and a companion, but also the pupil, who acquires an important role in decision making. The selection of topics and activities should be based precisely on the pupils' inclinations, interests, abilities, capabilities and affinities, on the stimulation of creativity and on the applicability of the activities in practical, everyday life.

Due to all of the stated reasons, we can conclude that extracurricular activities ought to be viewed as a mode of active learning, and that effort should be made so that, using previous good experiences of implementing and executing extracurricular activities as a foundation, they may reach a higher level and attain a contemporary developmental direction with the use of new proposals and stimulating measures.

\section{Methodology of the Empirical Research}

\section{Research Aims and Tasks Aims}

Examining the views and opinions of junior grade teachers/leaders of extracurricular activities on the organisation and implementation of extracurricular activities and on the promotion of the role of active learning.

Tasks

1. Determining the views of leaders of extracurricular activities on the significance of organisation and implementation as determinants in extracurricular activities

2. Determining whether importance is given to the stimulation of active learning in extracurricular activities in various areas of interest

3. Examining the leaders' views on stimulating factors that could contribute to the promotion of active learning within extracurricular activities 


\begin{tabular}{|c|c|c|}
\hline Areas of Interest & \multicolumn{2}{|c|}{ summary } \\
\hline \multirow{2}{*}{ linguistic/artistic area } & $\mathrm{f}$ & 110 \\
\hline & $\%$ & $42,64 \%$ \\
\hline \multirow{2}{*}{ sports/health/recreation } & $\mathrm{f}$ & 48 \\
\hline & $\%$ & $18,60 \%$ \\
\hline \multirow{2}{*}{ national and cultural heritage } & $\mathrm{f}$ & 31 \\
\hline & $\%$ & $12,02 \%$ \\
\hline \multirow{2}{*}{ environmental preservation } & $\mathrm{f}$ & 19 \\
\hline & $\%$ & $7,36 \%$ \\
\hline \multirow{2}{*}{ pupil cooperation } & $\mathrm{f}$ & 19 \\
\hline & $\%$ & $7,36 \%$ \\
\hline \multirow{2}{*}{ technical work } & $\mathrm{f}$ & 17 \\
\hline & $\%$ & $6,59 \%$ \\
\hline \multirow{2}{*}{$\begin{array}{l}\text { social and humanistic projects } \\
\text { and workshops }\end{array}$} & $\mathrm{f}$ & 7 \\
\hline & $\%$ & $2,71 \%$ \\
\hline \multirow{2}{*}{ natural science/mathematics } & $\mathrm{f}$ & 7 \\
\hline & $\%$ & $2,71 \%$ \\
\hline summary & $\%$ & $100,00 \%$ \\
\hline
\end{tabular}

Table 1 The areas of interest of the leaders of extracurricular activities

\section{Test Subjects}

Research was conducted in primary schools within the Primorje - Gorski Kotar County during the year of 2010, encompassing a sample of 258 leaders of extracurricular activities in the junior grades (1st to 4th grade) of primary school. Due to the fact that the polling was anonymous, only the geographic location, and not the name of the school was noted, and neither was the name of the activity noted, only its area of interest. The area of interest represents the independent variable in this study. Other data gathered on the test subjects (sex, geographical area, duration of work experience, duration of leadership of extracurricular activities) will not be displayed, as it is not relevant for the further data processing within the study.

From the areas of interest pertaining to extracurricular activities (Table 1), the leaders opted for the following areas: most subjects, $42.64 \%$ of them, executing activities from the linguistic/artistic area and $18.60 \%$ of subjects holding activities belonging to the field of sports/health/recreation. Following are the subjects leading activities in the area of national and cultural heritage $(12,02 \%)$. Subjects from the areas of environmental preservation, pupil cooperation and technical work share an approximately identical percentage of representation (7\%). A somewhat lesser representation of subjects, and also the lowest of all the percentages $(2.71 \%)$ was recorded in the areas of natural science/mathematics and in the area of social and humanistic projects and workshops. 


\section{Instruments}

For the needs of the research, a questionnaire on the implementation of extracurricular activities containing forty-three items was constructed. For the research needs of the work, within the questionnaire significance was given to the item of the stimulation of active learning within extracurricular activities. In this context, interpretation is focused exclusively on a factor obtained through a factor analysis of all item and named "Determinants of the Organisation and Leadership of Activities". The selected factor is composed of four variables: a clear definition of goals and activities, an appreciation of individual differences, the stimulation of active learning through contemporary strategies and an exclusive respect for the pupils' interests in their joining of the activity.

By application of a factor analysis of the questionnaire's items, the common factor method and an oblimin rotation, 5 factors with a characteristic root larger than 1 have been selected, accounting for $57 \%$ of the common variance. The normality of the result distribution was tested with the Kolmogorov-Smirnov test. The scale reliability was tested through the inner consistency of the results of the measurement, and the Cronbach-alpha coefficient was calculated. The inner consistency coefficient of the scale "Determinants of the organisation and leadership of activities" indicates a Cronbachalpha value of 0.83 , which can be interpreted as high and points towards the connection and dependence of items in the scale. The latent structure of the scale has been determined with a factor analysis, through the common factor method. After the extraction of the factors, a slanted direct oblimin rotation was performed.

\section{Results and Discussion}

\section{Significance Given to the Determinants of Organisation and the Leadership of Activities}

An effective implementation of extracurricular activities in the process of education presupposes a knowledge of didactic principles and acting according to them, the creation of activities that substantiate the purpose and goals of the programme through the knowledge of the pedagogical and didactic principles according to which the same are realised and, finally, an analysis to determine to what degree the planned goals have been realised.

A four-factor variable obtained through factor analysis, named the 'Determinants of the Organisation and Leadership of Activities" factor, describes the leaders' views on the significance of the implementation of activities in relation to: a clear definition of the goals and the content of the activities through which knowledge is acquired and the pupils' skills and abilities are developed, while respecting the individual differences between them. Added to this is the medium saturation of the variable of stimulating active learning through contemporary strategies, forms of work and cooperative teaching methods, as is that of the variable of exclusively respecting the pupils' interests in their joining of an activity. 


\begin{tabular}{|c|c|c|}
\hline $\begin{array}{c}\text { Variable } \\
\text { Determinants of the Organisation and Leadership of } \\
\text { Activities: }\end{array}$ & $\begin{array}{l}\text { Standardised } \\
\text { factor } \\
\text { coefficients }\end{array}$ & $\begin{array}{l}\text { Cronbach- } \\
\text { alpha } \\
\text { coefficient }\end{array}$ \\
\hline $\begin{array}{l}\text { A clear definition of the goals and the content of the activities } \\
\text { through which knowledge is acquired }\end{array}$ &,- 850 & 0,80 \\
\hline $\begin{array}{l}\text { Respecting individual differences between pupils(different } \\
\text { levels of previous knowledge, different interests and skills) }\end{array}$ &,- 774 & 0,79 \\
\hline $\begin{array}{l}\text { Stimulating active knowledge through contemporary strategies, } \\
\text { forms of work and cooperative teaching methods) }\end{array}$ &,- 674 & 0,75 \\
\hline $\begin{array}{l}\text { Exclusively respecting the pupils' interests in their joining of } \\
\text { an activity }\end{array}$ &,- 656 & 0,79 \\
\hline Cronbach-alpha coefficient 0,83 & & \\
\hline
\end{tabular}

Table 2 The factor Determinants of the Organisation and Leadership of Activities

The results indicate that leaders recognise the importance of a well thought out plan and programme with clearly defined goals, contemporary strategies and cooperative forms of work in the conduction of extracurricular activities. It is precisely the distinctiveness of a planned conception of extracurricular activities that offers a certain flexibility and innovativeness, in the sense that extracurricular activities do not imitate the content of regular lessons, but allow pupils' greater freedom in suggesting and deciding on a selection of topics that agrees with their fields of interest. In this manner, extracurricular activities disburden and liberate pupils from the rigidity of school, allowing the possibility for every school to be special and unique.

Therefore, openness in the organisation of extracurricular activities is necessary, one in the vein of Bašić's (2006) recommendations of open classes oriented towards the pupils' abilities, needs and interests, towards the interconnectedness between school and life, the self-definition of the individual and forms of learning based on active participation.

The importance that leaders of extracurricular activities give to the determinants of the organisation and leadership of activities is displayed on a Likert scale, with values for the significance of each variable ranging from 1 to 5 (from a stance that a leader gives no significance at all to the given determinant to a complete appreciation of the same).

In assessing the significance of a clear definition of goals, a respect for individual differences and the stimulation of active learning, not a single subject selected the option of 1 on the scale (I give no significance to this determinant of the organisation and leadership of activities). 


\begin{tabular}{|l|c|c|c|c|c|}
\hline \multicolumn{6}{|c|}{ Determinants of the Organisation and Leadership of } \\
\hline & Activities & M & Med & Mod & SD \\
\hline $\begin{array}{l}\text { Respecting } \\
\text { interests }\end{array}$ & 258 & 4.303 & 4.000 & 5.000 & 0.788 \\
\hline Defining goals & 258 & 4.392 & 4.000 & 4.000 & 0.614 \\
\hline $\begin{array}{l}\text { Individual } \\
\text { differences }\end{array}$ & 258 & 4.473 & 5.000 & 5.000 & 0.770 \\
\hline Active learning & 258 & 4.209 & 4.000 & 4.000 & 0.799 \\
\hline
\end{tabular}

Table 3 Descriptive statistics of the variable Determinants of the Organisation and Leadership of Activities

From a visual depiction (Graph 1) that ranks the mean arithmetic values of the significance of recognising the determinants of the organisation and leadership of activities, it is evident that the subjects evaluate all of the determinants as very significant. They give the largest significance to a respect for the individual differences between pupils, which presupposes different levels of previous knowledge and different interests and abilities $(M=4.47)$. The importance of giving significance to the individual differences between pupils and setting goals and planning activities with respect to them is a relevant indicator that the processes within extracurricular activities are focused on the development of the pupils. An almost equal importance given to the other determinants of the organisation and leadership of activities is reflected in the values for: a clear definition of goals and activities through which knowledge is acquired $(\mathrm{M}=4.39)$, an exclusive respect for the pupils' interests in their joining of an activity $(\mathrm{M}=4.30)$ and the stimulation of active learning through contemporary strategies, forms of work and cooperative teaching methods $(\mathrm{M}=4.21)$.

Recognition of the Determinants of the Organisation and Leadership of Activities

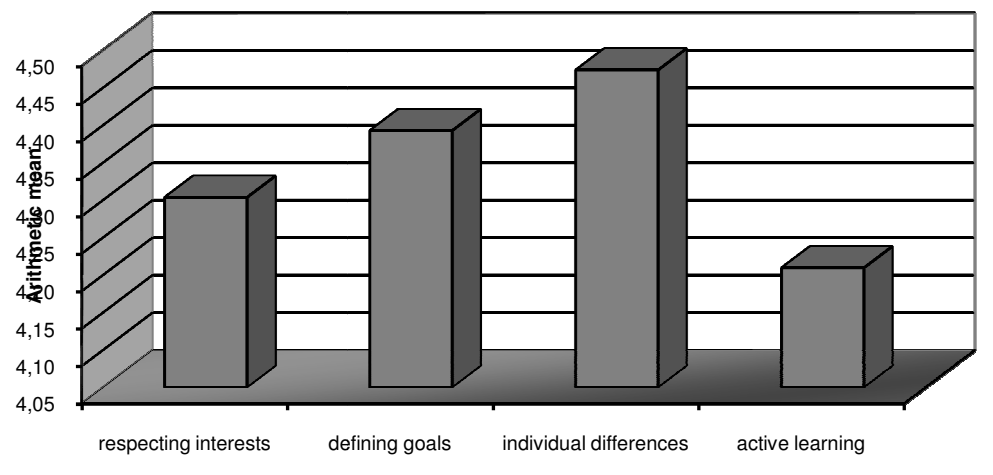

Graph 1 Determinants of the Organisation and Leadership of Activities

The Pearson correlation coefficient was also calculated in order to determine whether a connection between the determinants of the organisation and leadership of 
activities exists. A statistically significant positive connection between all the determinants was ascertained, with the strongest connection between the determinants of respecting the individual differences between pupils (different levels of previous knowledge, different interests and abilities) and that of a clear definition of the goals and activities through which knowledge is acquired, and the skills and abilities of pupils are developed $(\mathrm{r}=0.41 ; \mathrm{p}<0.05)$, as well as that of stimulating active learning through contemporary strategies, forms of work and cooperative teaching methods $(\mathrm{r}=0,36 ; \mathrm{p}$ $<0.05)$.

The exceptionally important educational role of extracurricular activities is reflected in the significance given to the determinants of the organisation and leadership of activities. Considering the fact that extracurricular activities are oriented towards respecting and giving importance to the pupils' interests, towards clearly set goals, contemporary work methods and activities whose content approximates that of reality and the needs and wishes of pupils they, with their openness and flexibility, contribute to the expansion of the pupils' personalities and the development of their knowledge.

\section{Stimulating Active Learning in Extracurricular Activities in Various Areas of Interest}

In extracurricular activities, teaching forms, methods and tools are adapted to the needs of a group of pupils and plans and preparations are made in order to satisfy their needs, all this while respecting their previous knowledge and experiences. In addition, work in extracurricular activities offers the opportunity for active and independent learning and for practical work. The method of executing educational work ought to be in the form of a workshop, project, group research or independent research, or in the form of field classes and/or other similar didactic and methodical approaches.

In order to determine whether there were differences between leaders belonging to eight areas of interest regarding the stimulation of active learning through contemporary strategies, forms of work and cooperative teaching methods in the implementation of activities, a unidirectional variance analysis was conducted. Leaders from eight areas of interest represented an independent variable (factor) according to which, during the execution of activities, active learning was stimulated through contemporary strategies, forms of work and cooperative teaching methods. The stimulation of active learning during the conduction of the activity represented the dependent variable (on a Likert scale ranging 1-5).

It was determined that there was a statistically significant difference between the groups when it came to stimulating active learning through strategies, forms of work and cooperative teaching methods during the execution of activities $(F(7,250)=9.22$; $\mathrm{p}<0.05)$, and that the degree of association was eta squared $\left(\eta^{2}=0.097\right)$, in which the leaders' areas of interest could account for $9.7 \%$ of the variance changes in the simulation of active learning through strategies, forms of work and cooperative teaching methods during the conduction of activities. 


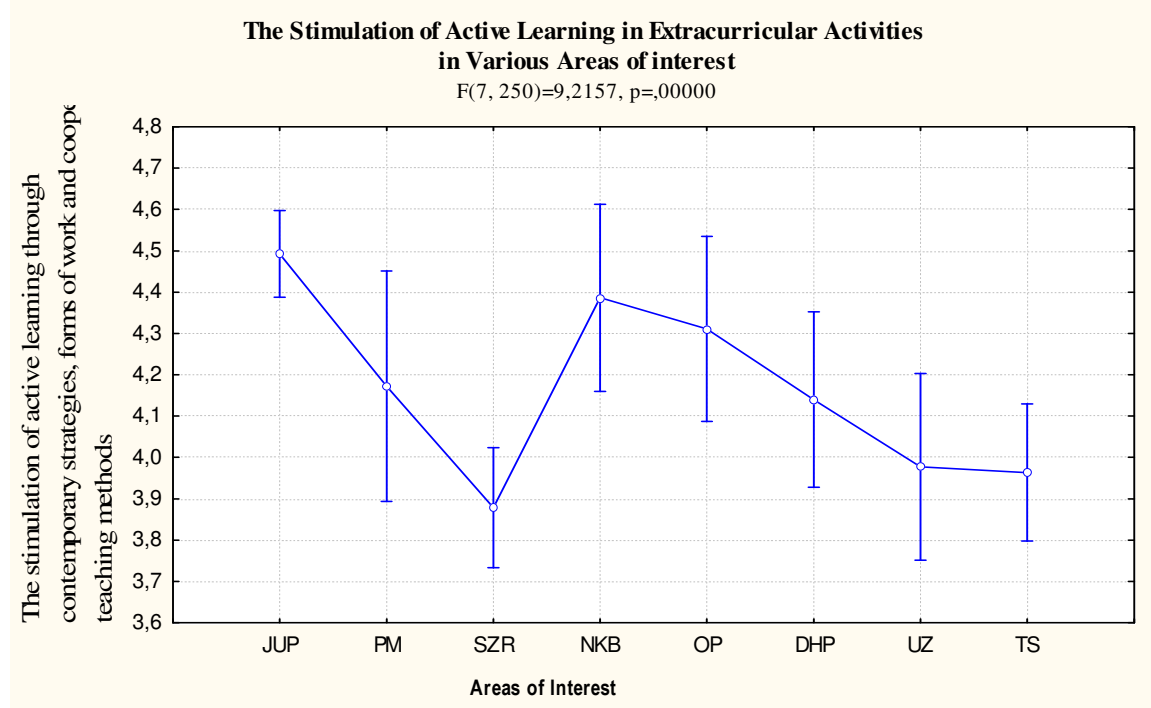

Graph 2 The Stimulation of Active Learning in Extracurricular Activities in Various Areas of Interest

By observing the effect displayed on Graph 2 it can be observed that, in the stimulation of active learning as pertaining to the recognition of the determinants of the organisation and leadership of activities, the greatest significance is given within the area of languages and arts, then in the area of national and cultural heritage and the area of environmental preservation. A somewhat smaller, almost equal percentage of giving significance to active learning was noted in the area of natural sciences and mathematics and in that of social and humanistic projects, while the percentage is significantly lower in the areas of pupil association and technical work. Active learning is least stimulated in the area of sports and health.

A Post-hoc pairwise Bonferoni multiple comparison determined that there is a statistically significant difference between the areas of sports/recreation/health $(\mathrm{M}=3.87$; $\mathrm{SD}=0.89)$, technical work $(\mathrm{M}=3.96 ; \mathrm{SD}=0,90)$ and pupil association $(\mathrm{M}=3.97$; $\mathrm{SD}=0.87)$ and the linguistic/artistic area $(\mathrm{M}=4,49 ; \mathrm{SD}=0.59)$, and the area of fostering national and cultural heritage $(\mathrm{M}=4.38 ; \mathrm{SD}=0.65)$, as well. Statistically significant differences can also be noted between the area of preserving nature, the environment and a healthy lifestyle $(\mathrm{M}=4.31 ; \mathrm{SD}=0.66)$, and the sports / health / recreation area $(\mathrm{M}=3.87$; $\mathrm{SD}=0.89$ ). There were no statistically significant differences between other areas.

Due to the variety of activities on offer, the areas of interest that proved to stimulate active learning the most were those that used creative teaching as a starting point, utilising strategies and methods that stimulate creative thinking, cooperative and experiential learning to improve understanding and the application of acquired knowledge. The areas of interest that give less significance to the stimulation of active learning ought to be viewed in light of a positive co-dependance, group responsibility and group processing according to already settled rules. 


\section{Assessment of the Factors That Stimulate Active Learning}

The unattractiveness of the programme of a certain activity is reflected in the dearth of opportunities given for independent learning and practical work through methods of execution that ought to primarily be in the form of workshops, projects or group research didactic and methodical approaches. In order to perform an assessment of stimulating factors pertaining to the determinant of the organisation and leadership of activities in connection with the stimulation of active learning through contemporary strategies, forms of work and cooperative teaching methods, a t-test for dependent samples was conducted.

In most assessments of stimulating factors (school equipment, rewards to leaders, support from the environment), the significance of the leaders' exchange of experiences relating to the leadership of extracurricular activities particularly stands out $(\mathrm{M}=3.46$; $\mathrm{SD}=1.64 ; \mathrm{t}(258)=13.74 ; \mathrm{p}<0.05)$, as does the organisation of professional training programmes for the conduction of extracurricular activities $(\mathrm{M}=3.81 ; \mathrm{SD}=0.88 ; \mathrm{t}(258)=$ 9,74; $\mathrm{p}<0.05)$.

A teacher who is prepared to conceptualise and shape, and to stimulate students to create by using the aforementioned work methods, expects and estimates that professional training, including a demonstration and exchange of experiences, would certainly aid the processes of active learning for pupils. Opportunities for the improvement of our practice in extracurricular activities are severely lacking, or even completely absent.

In order for them to achieve professional development in the organisation and implementation of extracurricular activities, teachers ought to be constantly given the opportunity for professional training ${ }^{2}$ (seminars, workshops, lectures, reading materials), so that they may follow the current events in the area that they pursue. On one hand, teachers ought to be motivated to invest effort, time and energy in their own professional development ${ }^{3}$, however, on the other, the school also has to be an environment that supports development. An environment in which people are open to new ideas, ready for change and willing to develop new skills and abilities has to be created. This primarily implies all those changes that demand new organisational abilities and a collective intelligence. In this vein, the demand to develop their own personal learning strategies and to understand the context which they work in is put before teachers. A relaxed, informal environment leads to a physiological and emotional state that is favourable for learning (Jensen, 2003), while cooperation contributes to better relations within the school and develops cooperative relationships.

\footnotetext{
${ }^{2}$ The professional training of teachers and professional associates (according to Article 2 of the State Pedagogical Standards for Primary School Education, 2008) - the continuous professional development of teachers and professional associates through official or unofficial, group or individual forms of education and acquisition of additional knowledge and skills, with the aim of furthering personal abilities and skills in one's own profession and educational work in general.

${ }^{3}$ The professional development of a teacher ought to be thought of as a continuous, lifelong process, one in which the professional knowledge of a teacher is questioned, revised and gradually built upon through a mutual exploration of one's own practice.
} 
The ways in which to realise goals and tasks through active learning within extracurricular activities depend on the work conditions, cooperation and the needs of the school and the wider community but, above all, on knowledge of diversity and the application of contemporary forms, methods and strategies of work.

\section{Conclusion}

Extracurricular activities represent planned educational work realised within the school, allowing the teacher an expanded educational influence on the pupil. The research results indicate that leaders of extracurricular activities recognise the importance of a well thought out plan and programme with clearly defined goals in the conduction of an activity, as well as of the use of contemporary strategies and cooperative forms of work. In their recognition of the determinants of the organisation and leadership of activities, leaders give most significance to respect for the individual differences between pupils; to a clear definition of goals and activities through which knowledge is acquired and the pupils' skills and abilities are developed; to an exclusive respect of the pupils' interest in their joining of an activity and to the stimulation of active learning through contemporary strategies, forms of work and cooperative teaching methods, which reflects the exceptionally important educational role that extracurricular activities play in their focus on the pupils' development. Moreover, the results point towards significant differences in the stimulation of active learning pertaining to the area of interest of the extracurricular activity in question. Active learning is given most significance within the linguistic/artistic area, the area of national and cultural heritage and the area of environmental preservation. In order to promote active learning through contemporary work strategies in extracurricular activities as much as possible, in their assessment of stimulating factors the leaders deem that an exchange of experiences relating to the leadership of extracurricular activities between leaders, as well as the organisation of professional training programmes for the management of extracurricular activities is necessary. In the realisation and management of extracurricular activities, one ought to strive towards stimulating and developing the creative abilities of every pupil, doing so with a quality programme and various contemporary approaches and strategies.

\section{Bibliography}

Baker, E. L. (2002), Teacher Use of Formal Assessment in the Classroom. In: The Keys to Effective Schools (ed. Hawlwy, W. D.), California, Thousand Oaks: Corwin Press.

Bartlett, S. (2003), Education for Lifelong Learning. In: Education studies (ed. Bartlett, S. Burton, D.), London: SAGE Publications.

Bašić, S. (2006), Otvorena nastava kao teorijski konstrukt, Pedagogijska istraživanja, 3(1), 2132.

Black, S. (2002), Extracurricular activities and academic performance go hand in hand, American School Bord Journal, June 2002, Vol. 189, No. 6.

Butt, G. (2003), Lesson planing. New York: Continuum. 
Cindrić, M. (1992), Izvannastavne i izvanškolske aktivnosti učenika osnovne škole. U: Život $i$ škola, 41 (1), Zagreb: Zavod za školstvo Ministarstva prosvjete i kulture Republike Hrvatske, pgs 4968.

Cota Bekavac, M. (2002), Istraživanja suradničkog učenja. Napredak, 143(1); 32-40.

Ilišin, V. (2002), Interesi i slobodno vrijeme mladih. U: Mladi uoči trećeg milenija. Zagreb: Biblioteka znanost i društvo, 269-302.

***Državni pedagoški standardi (2008), Zagreb: Ministarstvo znanosti, obrazovanja i športa.

Jensen, E. (2003), Super-nastava. Nastavne strategije za kvalitetnu školu i uspješno učenje. Zagreb: Educa.

***Katalog natjecanja i smotri učenica i učenika osnovnih i srednjih škola Republike Hrvatske u 2007. godini. (2006), Zagreb: Agencija za odgoj i obrazovanje.

Marzano, R. J. i dr. (2006), Nastavne strategije. Zagreb: Educa.

Mc Hale, S. M., Crouter, A. C., Tucker, C. J. (2001), Free-Time Activities in Middle Childhood: Links with Adjustment in Early Adolescence. Child Development. 72(6), pgs 1764-1778.

McIntosh, H., Schmidt, J., Chang, F. (2001), Predictors of Positive Cooperative Behavior in Youths. New direction for children adolescent development, 93, 150-164.

Molnar, A. (ur.) (2002), School reform proposals: The research evidence. Greenwich, CT: Information Age Publishing.

***Nastavni plan i program (2006), Zagreb: Ministarstvo znanosti, obrazovanja i športa.

***Pedagoška enciklopedija (1989), Beograd: Zavod za udžbenike i nastavna srdstva.

Pejić Papak, P. (2008), Suvremenim se oblicima aktivnog učenja učenik penje uz piramidu znanja. U: Pedagogy and the Knowledge Society (ur. Cindrić, Domović, Matijević). Učiteljski fakultet Sveučilišta u Zagrebu. Zagreb.Vol.2, 255-264.

Pivac, J. (2009), Izazovi školi. Zagreb: Odsjek za pedagogiju Filozofskog fakulteta Sveučilišta u Zagrebu i Školska knjiga.

***Plan razvoja sustava odgoja i obrazovanja 2005. - 2010. (2005), Zagreb: Ministarstvo znanosti, obrazovanja i športa.

Plenković, J. (2000), Slobodno vrijeme mladeži. Rijeka: Sveučilište u Rijeci.

Previšić, V. (1987), Izvannastavne aktivnosti i stvaralaštvo. Zagreb: IGRO „Školske novine".

Previšić, V. (ur.) (2007), Kurikulum. Teorije-metodologija-sadržaj-struktura. Zagreb: Zavod za pedagogiju Filozofskog fakulteta Sveučilišta u Zagrebu i Školska knjiga.

Puževski, V. (1988), Izvannastavne i izvanškolske aktivnosti u funkciji suvremenih tokova odgoja i obrazovanja. U: Nastavnik u izvannastavnim i izvanškolskim aktivnostima, Rijeka: Pedagoški fakultet u Rijeci, pgs 17-29.

Reed, L. Seepersad, S. (2003), Adolescents' Leisure Time in the United States: Partying, Sports, and the American Experiment. New direction for children adolescent development, 99, pgs 5363.

Robinson, J. (2003), Contemporary Globalization and Education. In: Education Studies. (ed. Bartlett, S. Burton, D.), London: SAGE Publications.

Strugar, V. (2003), Aktivno stjecanje znanja: poučavanje i učenje u svijetu koji se mijenja. U: Promjenama do uspješnog učenja i kvalitetne škole (ur. Hrvoje Vrgoč), Zagreb: Hrvatski pedagoškoknjiževni zbor.

Vidulin-Orbanić, S. (2007a), Organizirano provođenje slobodnog vremena kroz izvannastavne glazbene aktivnosti. U: Pedagogija - prema cjeloživotnom obrazovanju i društvu znanja (ur. Previšić, Šoljan, Hrvatić), svezak 2, pgs 733-743.

Vidulin-Orbanić, S. (2007b), Izvannastavne (glazbene) aktivnosti: mjesto suživota, kreativnosti i stvaralaštva, Rovinj: OŠ Vladimira Nazora. 
Vrkić Dimić, J. (2007), Socijalni konteksti slobodnog vremena mladih. U: Pedagogija-prema cjeloživotnom obrazovanju i društvu znanja (ur. Previšić, Šoljan, Hrvatić), svezak 2, pgs 744-751.

Metodički obzori 6(2011)2

Izvorni znanstveni rad

UDK: 379.81-052.5

Primljeno: 14. 8. 2010.

\title{
POTICANJE AKTIVNOG UČENJA SUVREMENIM STRATEGIJAMA RADA U IZVANNASTAVNIM AKTIVNOSTIMA
}

\author{
mr. sc. Petra Pejić Papak \\ Sveučilište u Rijeci \\ Učiteljski fakultet u Rijeci \\ e-mail: petra@ufri.hr \\ dr. sc. Sabina Vidulin-Orbanić \\ Sveučilište Jurja Dobrile u Puli \\ Odjel za glazbu, Odsjek glazbene pedagogije \\ e-mail: sabina.glazba@gmail.com
}

\begin{abstract}
Sa žetak
Umijeće uspješne pripreme i vođenja nastavnog procesa, uporabe prikladnih postupaka, metoda, oblika interakcije, medija i tehnologije odlikuje suvremenu školu. Otvaranje škole potrebama mladih i nakon redovite nastave važno je kako bi škola nastavila širenje svoje odgojno-obrazovne uloge i u slobodnom vremenu učenika. Stoga, izvannastavne aktivnosti jesu i ostaju učinkovito mjesto za ostvarenje suvremenih odgojno-obrazovnih ciljeva i mjesto na kojemu se uspješno primjenjuju suvremene nastavne strategije s ciljem razvoja učenika i njegova napretka. Učenik je u prilici sudjelovanjem u različitim izvannastavnim aktivnostima, na različitim tematskim sadržajima, samoučenjem, aktivnim sudjelovanjem i individualnim (samo)razvojem koristiti različite strategije rada. Suvremenim strategijama organizira se slobodniji rad učenika kako bi povezivanjem teorije i prakse proširili i produbili stečena znanja, razvili svoja umijeća, ali i postali aktivnim učesnicima kulturnih događanja u svom okružju. Istraživačkim pristupom na uzorku od 258 voditelja izvannastavnih aktivnosti nižih razreda svrha ovog rada bila je utvrditi stavove voditelja o pridavanju značaja odrednicama organizacije i provedbe izvannastavne aktivnosti, poticanju aktivnog učenja suvremenim strategijama unutar interesnih područja te utvrđivanju poticajnih čimbenika koji bi pridonijeli promicanju aktivnog učenja u izvannastavnim aktivnostima.
\end{abstract}

Ključne riječi: osnovna škola, izvannastavne aktivnosti, suvremene strategije, aktivno učenje, voditelji izvannastavnih aktivnosti 